\section{B A Institute of \\ YK Business Administration \\ 六下 \\ Karachi \\ Leadership and Ideas for Tomorrow}

Business Review

Volume 3 Issue 1 January-June 2008

$1-1-2008$

\title{
SMEs in globalized world: A brief note on basic profiles of Pakistan's small and medium scale enterprises and possible research directions
}

Sarath W.S.B. Dasanayaka

University of Moratuwa, Sri Lanka

Follow this and additional works at: https://ir.iba.edu.pk/businessreview

Part of the Entrepreneurial and Small Business Operations Commons

\section{(c) (7)}

This work is licensed under a Creative Commons Attribution 4.0 International License.

\section{Recommended Citation}

Dasanayaka, S. W. (2008). SMEs in globalized world: A brief note on basic profiles of Pakistan's small and medium scale enterprises and possible research directions. Business Review, 3(1), 69-78. Retrieved from https://doi.org/10.54784/1990-6587.1133 


\title{
ARTICLE
}

\section{SMEs in Globalized World: A Brief Note on Basic Profiles of Pakistan's Small and Medium Scale Enterprises and Possible Research Directions}

\author{
Sarath W.S.B. Dasanayaka \\ University of Moratuwa, Sri Lanka
}

\begin{abstract}
The Small and Medium Scale Enterprises (SMEs) are playing very significant role in almost all the economies around the world in irrespective of the countries development stage. However it is obvious that SMEs function as a lifeline in informal sector in Asia, Africa, Latin America and Eastern Europe due to their contribution to overall economy in many aspects such as employment generation, exports, tax income, innovation, competitiveness, equitable income distribution, social stability, domestic resources usage, regional development and ultimately it is the main source of economic growth. The Pakistan is no exception to this phenomenon as a developing country located in South Asian region. Most of these SMEs around the world are struggling to survive in today's globalized competitive economy. They are hampered by the lack of technology, access to credits and markets, lack of infrastructure and competition from foreign products, etc. In spite of the various policy reforms, setting up of SMEs promotional apex bodies, incentives and assistance offered by successive governments in Pakistan with the assistance of private sector, NGOs and donor agencies since political independence, still this SME sector is less dynamic and underdeveloped as against large-scale enterprises in the national economy. The growth and expansion of SMEs are constrained by problems relating to both product and factor markets in Pakistan. Lack of policy and conducive supportive environment, sub sector strategies and cluster development with business development services have further reduced the full potential contribution of SMEs to the national economy. In this context this brief note is covering basic facts about Pakistan SMEs and present an agenda for future SMEs research in Pakistan.
\end{abstract}

Key Words: SMEs, basic profiles, research agenda, Pakistan

\section{INTRODUCTION}

The first part of this paper highlights the various aspects of SMEs in terms of their basic profiles such as definitional problems, sector-wise distribution and their 
contribution to Pakistan economy by using various data indicators. Finally, tentative conclusions and an agenda for Pakistani's SMEs research will be presented.

\section{DEFINITION OF SMES IN PAKISTAN}

The Pakistan SMEs are engaging in wide range of business activities in agriculture, mining, fishing, industry/manufacturing, construction, retails and whole sales and services in rural, urban and estate settings by servicing local and international markets.

They are active in most of the industry sub sectors such as agricultural inputs/outputs business in rural areas to food and beverages business in city up to more advanced light engineering sectors such as computer, chemical, machinery, apparel and construction business in local and foreign markets. Most Pakistan SME's are oneperson show or are run by few family individuals, usually relatives, friends or business partners, who take most of the decisions. Usually no distinction between private and business assets, and subjective and personal factors play a large role in decision-making. The personal stakes of Pakistan SMEs have in their businesses are much higher than those of corporate executives in their companies. This enhances the attendant risks and commits entrepreneurs even more strongly to the success of their enterprises. Most Pakistani SMEs in informal sector are reporting very low productivity and income therefore owners and workers are 'working poors' but SMEs in formal sector report very high productivity and efficiency and provide very high income and decent life for workers and owners. This wide variation of diversity in Pakistan SMEs bring various types of assets, employees, skills, capital, turnover/revenue, sophistication, innovation, productivity and growth orientation. Due to this complexity, it is very hard to define SMEs overtime in Pakistan and currently nationally acceptable single definition is not available. There are very many definitions available based on assets, employees, skills, capital, turnover/revenue in local and exports markets, sophistication, innovation, productivity and growth orientation. But most of these definitions are made according to organizational needs and purpose of interests about SMEs. Financial institutions, public sector authorities, non-governmental organizations (NGOs), trade and industry chambers, international organizations, researchers, SMEs service providers and consultancy firms have their own definitions based on their own criteria selection. Most of these organizations used various terms for SMEs such as Small and Medium Scale Industries (SMIs), Micro Enterprises (MEs), Rural Enterprises (REs), Small and Medium Scale Activities (SMAs), Cottage and Small Scale Industry (CSSI), Informal Sector Activities (ISAs), Micro and Small Scale Activities (MSSA), etc. Generally, enterprise is defined as any business activity or entity engaged in industry, agri-business and/or services whether single proprietorship, partnership or corporate venture. This enterprise definition is universally accepted around the world. The following table shows most popular definitions on SMEs available in Pakistan. 
Table 1 - Definition of SMEs in Pakistan

\begin{tabular}{|c|c|c|c|}
\hline Institution & Criterion & Medium Scale & Small Scale \\
\hline $\begin{array}{l}\text { Small and Medium } \\
\text { Enterprise } \\
\text { Development } \\
\text { Authority } \\
\text { (SMEDA) }\end{array}$ & $\begin{array}{l}\text { No. of Employees } \\
\text { Productive assets }\end{array}$ & $\begin{array}{l}\text { Between } 36 \text { - } 99 \\
\text { 20- } 40 \text { Million PKR }\end{array}$ & $\begin{array}{l}\text { Between } 10-35 \\
2-20 \text { Million PKR }\end{array}$ \\
\hline SME Bank & Total assets & Over 100 Million PKR & $\begin{array}{l}\text { Less than } 100 \text { Million } \\
\text { PKR }\end{array}$ \\
\hline $\begin{array}{l}\text { Federal Bureau of } \\
\text { Statistics }\end{array}$ & No. of Employees & N/A & $\begin{array}{l}\text { Less than } 10 \\
\text { employees }\end{array}$ \\
\hline $\begin{array}{l}\text { State Bank of } \\
\text { Pakistan }\end{array}$ & $\begin{array}{l}\text { Nature of the } \\
\text { business } \\
\text { (Manufacturing } \\
\text { Trade/Services) } \\
\text { No. of Employees } \\
\text { Capital employed } \\
\text { Net sales value }\end{array}$ & $\begin{array}{l}\text { Less than } 250 \\
\text { employees and less } \\
\text { than } 100 \text { million PK } \\
\text { Rs. assets for } \\
\text { manufacturing. } \\
\text { Less than } 50 \\
\text { employees and less } \\
\text { than } 50 \text { million PK Rs. } \\
\text { for trade/services. } \\
\text { Net sales less than } 300 \\
\text { million PKR }\end{array}$ & $\begin{array}{l}\text { Less than } 250 \\
\text { employees and less } \\
\text { than } 100 \text { million PK } \\
\text { Rs. assets for } \\
\text { manufacturing. } \\
\text { Less than } 50 \\
\text { employees and less } \\
\text { than } 50 \text { million PK Rs. } \\
\text { for trade/services. } \\
\text { Net sales less than } 300 \\
\text { million PKR }\end{array}$ \\
\hline $\begin{array}{l}\text { Sindh Industries } \\
\text { Dept. }\end{array}$ & $\begin{array}{l}\text { Nature of the } \\
\text { business } \\
\text { Total Investment } \\
\text { including land and } \\
\text { buildings }\end{array}$ & $\begin{array}{l}\text { Handicrafts or } \\
\text { manufacturing capital } \\
\text { investment less than } \\
10 \text { million PKR }\end{array}$ & $\begin{array}{l}\text { Handicrafts or } \\
\text { manufacturing capital } \\
\text { investment less than } \\
10 \text { million PKR }\end{array}$ \\
\hline $\begin{array}{l}\text { Punjab Industries } \\
\text { Dept. }\end{array}$ & $\begin{array}{l}\text { Value of assets } \\
\text { other than } \\
\text { buildings and } \\
\text { lands. }\end{array}$ & $\begin{array}{l}\text { Less than } 10 \text { million } \\
\text { PKR }\end{array}$ & $\begin{array}{l}\text { Less than } 10 \text { million } \\
\text { PKR }\end{array}$ \\
\hline $\begin{array}{l}\text { Punjab Small } \\
\text { industries } \\
\text { corporation }\end{array}$ & $\begin{array}{l}\text { Capital investment } \\
\text { excluding lands } \\
\text { and building }\end{array}$ & $\begin{array}{l}\text { Less than } 20 \text { million } \\
\text { PKR }\end{array}$ & $\begin{array}{l}\text { Less than } 20 \text { million } \\
\text { PKR }\end{array}$ \\
\hline $\begin{array}{l}\text { Pakistan Tax } \\
\text { Ordinance (2005) }\end{array}$ & $\begin{array}{l}\text { Equity } \\
\text { Turn over }\end{array}$ & & $\begin{array}{l}\text { Less than } 25 \text { million } \\
\text { PKR } \\
\text { Less than } 200 \text { million } \\
\text { PKR }\end{array}$ \\
\hline
\end{tabular}

Source: SMEDA, Pakistan 2006 and Author of the article.

In addition to this, various banks, financial institutions, donor agencies, NGOs, industry related task forces, trade and industry chambers adopted their own definitions for SMEs for their convenience and objectivity of studying SMEs. But almost all these definitions adopted their main criteria as no. of employees, capital 
employed/total assets and turnover. But these criteria have its own limitations overtime and need changes with technology improvement, productivity increases and inflation, etc. Very recently in Pakistan for this SME equation, Micro and Cottage enterprises also came and now Micro, Cottage and Small Scale Enterprises are in picture and in most cases medium scale enterprises are out from the equation. Some policy makers and researchers in Pakistan have pointed out that micro, cottage (less than five employees) and small enterprises should receive government more care and attention not the medium scale enterprises and they have many justifications for that. However overtime this SMEs definition criteria should be changed to fit with changing economic, technology and productivity scenarios. In addition to this various other criteria and range of values should be assigning to define SMEs sector as a whole and sub group-wise. Still in Pakistan, SMEs data base mainly concentrated on manufacturing rather agriculture and service activities. Therefore researchers and authorities should take steps to expand SMEs data base from manufacturing to agriculture and service sectors while finding a proper definition for SMEs and change it overtime looking at the market changes. Recently SMEDA appointed SMEs working committee on SME definition vested power to come up with new definitions for SMEs, micro and large scale industries to more specifically target incentives to promote and develop SMEs.

\section{3) DATA ANALYSIS ON PAKISTAN'S SMEs}

The Pakistan's SMEs data base is very fragile and unreliable due to regular change of survey units definitions, partial sector wise coverage with bias to manufacturing, too aggregative nature of the data, non-continuity of surveys, non-compilation of data on important aspects such as overall and sector wise SMEs contribution to value added and net foreign exchange, some parts of the country data can not access due to arms conflict and many organizations involvements in SMEs data compilation, etc. The most reliable data base available with government three statistical bureaus (now these three bodies amalgamated). But that also do not specifically give exact contribution of SMEs alone. But we assume that Pakistan is naturally a SME economy and more than $98 \%$ of its enterprises are SMEs (SMEDA, 2005). Normally industrial or establishment surveys cover all size of enterprises and therefore it is very hard to separate data for SMEs due to aggregative nature and survey definitions changes overtime. But most of the enterprises/industries data in household level can assume as micro or small scale and establishment level data as medium and large scale enterprises. Available data mainly categorized under the region-wise (Punjab, Sindh, NWFP, Baluchitan and Islamabad) and urban and rural-wise.

The latest available data on Economic Survey of Pakistan 2003-04 reveals that SMEs contribution to manufacturing sector in terms of GDP around 30\%, employment $80 \%$, export $25 \%$ and value addition $30 \%$. More details information available on industrial survey for year 2000 (Federal Bureau of Statistics in Pakistan, 2000). 
These survey data show that in geographical location-wise of enterprises/industries, 65\% enterprises are located in Punjab, 18\% in Sindh, 14\% in NWFP and other 3\% in Balochistan and Islamabad. In concentration of enterprises, 53\% are wholesale, retail, restaurants and hotels, 22\% community, social and personal services and $20 \%$ are in manufacturing. In rural, urban and house holds wise also this concentration is holding true. More than $96 \%$ of establishments belong to less than 5 employee category and this is true for region-wise also. This may be a good area to further research to see that most Pakistan establishments are micro level rather SMEs. Another interesting fact is that ownership-wise more than $96 \%$ enterprises are belonging to individuals and this picture hold true for regions as well. In age wise, more than $90 \%$ of SMEs are less than 20 years old and this picture holds for rural and urban areas as well. This may be the main obstacle to access to finance. Generally small and very young SMEs have many obstacles to access to finance and credits markets.

In analyzing ISIC (two digit) industry categories a large proportion of industries are concentrated on few categories: $43 \%$ industrial establishment are in textile, apparel and leather, $20 \%$ in food, beverage and tobacco, $10 \%$ in wood and wood products, $10 \%$ in metal and fabricated metal sector and $8 \%$ in handicrafts and related other activities. This shows Pakistan's industrial concentration in textile, apparel and leather sector and foods and beverages sectors. Even in region and rural and urban area wise this picture holds true. This may be the right message policy makers to think to diversify Pakistani industrial structure.

In terms of employment status more than $70 \%$ of employees are unpaid family workers, partners and self employed people and this is very clearly visible in Pakistan's house hold level enterprises and it is truly valid for rural, urban and region-wise as well. In gender-wise, female participation is very less even in paid or unpaid, partnerships and self-employed areas. In overall female labour participation is $7 \%$. And it is $3 \%$ in unpaid, partnerships and self-employed areas. In rural, urban, households, and region -wise this picture holds true.

Building status wise in overall establishments more than 58\% are running their business in rented buildings and this is true in urban-wise (74\%) but rural-wise majority of business are conducting in their own premises. More than $99 \%$ establishment employed capital (not included land and buildings) is less than one million PK Rs. And this picture holds true for rural, urban and region-wise. More than $97 \%$ of Pakistan enterprises are earning less than 20 million PK Rs. per year and this is hold true in region-wise as well.

SMEs are naturally labour intensive and therefore they contribute heavily for employment, income distribution and poverty eradication. More than $98 \%$ of Pakistan enterprises in terms of urban, rural and region-wise employ less than 10 persons. 


\section{4) TENTATIVE CONCLUSIONS}

The universally acceptable official definition for SMEs not available in Pakistan overtime as the case in most developing countries and all the existing definitions depend on convenience and objectivity of studying SMEs. But almost all these definitions adopted their main criteria as no. of employees, capital employed/total assets and turnover in local or foreign markets. But these criteria have its own limitations overtime and need changes with technology improvement, productivity increases and inflation, etc. Still in Pakistan, a separate SMEs data base is not available and generally all the surveys (except a very few) or census at establishment level collect data on rural, urban and region-wise. Therefore researchers and authorities should take steps to expand SMEs data base regularly covering manufacturing, agriculture and service sectors while recommending a proper definition for SMEs overtime.

$>\quad$ Heavy concentration of SMEs and their supportive organizations in urban areas in Pakistan may be the reason for urban bias unequal development pattern in country. Therefore some polices and strategies have to design to promote SMEs in more disadvantageous regions and SMEs related organizations to provide services for underdeveloped rural areas as well. Furthermore, the non-diversification of Pakistan industrial structure and its heavy concentration in the few low value added industry categories is a main problem for sustainability of industrial development. This may be a valid point for policy makers to take up and to formulate strategies to diversify the Pakistan industrial structure to create more value addition to local economy and to increase resilience of the economy.

$>\quad$ In Pakistan's the main heart of industry is Punjab and most SMEs are very young and owned by individuals and concentrates in service sector activities. In ISIC (two digit) industrial activities they are concentrated on few areas such as textile, apparel, leather, food and beverages sectors.

$>$ General assumption is that SMEs is the main contributor for generation of employment and value added in any economy. But that is very hard to prove through the available Pakistan data base. For instance, all the available industry census/survey data confirmed that in terms of number of establishments SMEs account for over $98 \%$ employment and enterprises but value added data not collected. However, manufacturing sector-wise value added data available for some years without specifically stating SMEs contribution (SMEDA/ILO: 2002, Bary. F and et.al:2001, 2003). These data shows that large scale industries generate more value addition compared with SMEs.

$>\quad$ There are very many organizations and institutions involve in development and promotion of SMEs in Pakistan but overall coordination is very poor among them. In 1998 Pakistan set up SMEDA as an apex body for development and promotion of SMEs. But still most SMEs promotion bodies not under SMEDA and therefore naturally resource wastage and confusion 
among the SMEs is quite normal. It seems like better coordination among various SME stakeholder are badly necessary. Furthermore, the government SME support institutional setup seems like very complex and systems and procedural oriented. Therefore, it should be simplified and customer driven. But government can implement regionalization with centralization and uniformity with diversity in their SME supportive systems and delivery mechanism looking at the special characteristics of regional SMEs. The decentralization of government SMEs supportive organizations and structure may be good to provide more flexible, responsive and customer driven service to the informal sector SMEs who badly need these business development assistance.

$>$ SMEDA and SME Bank may be the right places to start this overall coordination of SMEs promotion and development initiatives. Especially proper coordination of various SME stakeholders (government institutions, private sector, NGOs and donors) are badly necessary. But problem is skills and capacities of the above two organizations and trust of SMEs about the efficiency and customer driven-ness of these organizations. Especially SMEDA has to undergone severe restructuring and image building to suit with current needs of Pakistan SMEs. Just appointing expensive committees or formation of common facility centers may be not the solution to SMEs complex problems. Private sector BDS providers should strengthen through fiscal measures and regulatory bodies to give more quality services to regional SMEs and government can take facilitator role in providing services to SMEs through BDS providers by coordinating their activities through regional trade and industry chambers.

\section{5) FUTURE RESEARCH DIRECTIONS FOR PAKISTAN'S SMEs}

1) Research agenda need to identify key issues in SMEs in informal sector in Pakistan that are currently affecting operations of SMEs. Can promote research to undertake diagnostic review of public, private, NGOs and donors supported SME institutions. It is better to document earlier SME sector studies, current SME programmes and activities, main donors, policies being implemented and key policies affecting small rural enterprises.

2) Research necessary to identify training needs of SME support institutions and same time can promote case study to see effectiveness of regional programming strategy of key aid agencies working in Pakistan and make a catalogue of rural SME development interventions that highlights successful examples of rural SME development in Pakistan.

3) Research necessary to identify and make recommendations of priority sectors and sub-sectors of SMEs that could be supported and promoted with potential for value addition, employment creation and growth in exports.

4) Research agenda needs to analyze the activities of financial institutions, particularly banks, serving rural areas by defining a range of financial products 
offered in rural areas, evaluating whether the supply of products/services fits local needs and highlighting supply shortfalls and potential opportunities.

5) Research necessary to design operational guidelines providing standards and performance indicators, which donors, NGOs and Government interventions /programmes in rural areas should comply with.

6) More empirical research are necessary to frame national policy framework, strategies, operational guidelines, institutional set-up and support, network development strategies and an implementation plan to a workshop of key stakeholders, providing options for Government consideration. Same time sub research agenda can workout to identify, design and deliver targeted capacity building initiatives for networks and support institutions to support strategy.

7) How far we can use ICT related various E-commerce applications and tools to promote and develop various aspects of SMEs. Especially SMEs competitiveness, productivity, efficiency, operational and production process and connectivity and networking be improve by using ICT may be good areas to research.

8) Research on productivity differences in small, medium and large scale enterprises and their various implications are necessary in Pakistan context (World Bank/SMEDA, 2003). Especially better to explore why competitive markets are not automatically ensure that less productive firms are forced out? Why market leave room for bigger firms with higher productivity but less potential to create employment and social justice? Why is it that small firms still dominate the economic structure even in more developed economies? What is their competitive advantage? Should development strategies ignore small-scale activities in order to raise overall productivity of economies? Does the dominance of small firms hinder or harm poverty reduction? Or is there a way to enhance productivity growth in small and medium enterprises?

9) More quantitative research are necessary to see the exact relationships between the share of employment and value added in SMEs and its relationships to growth of GDP in econometric terms. And the same time more scientific research can be promoted to further develop SMEs vicious cycle idea (Dasanayaka.S: 2006a) and to find strategies and means to break it. Furthermore, SMEs stakeholder integration framework (Dasanayaka.S: 2006b) can be further develop to link the various SMEs stakeholders.

10) Re-establishment and rehabilitation of recent earth quake affected Pakistan SMEs is very slow even with floods and rains of foreign and local assistance to this area. Therefore, action oriented research necessary to find out reasons for this failure and to find new framework and model to implement for disaster affected SMEs rehabilitation.

11) More research can be promoted to see the technology management issues in important SME sub sectors or industry clusters in Pakistan. Especially various business incubator models can be experimented to Pakistan looking at the best practices around the world (Nelson.O and Dasanayaka.S, 2006). 
12) An applied research project can be promoted to see an effectiveness of Pakistani SME apex bodies operational strategies in terms of costs/benefits or impact assessment studies. Especially effectiveness of SME clusters and common facility centers may be right start point for research.

\section{REFERENCES}

Bari, Faisal, Cheema, Ali, and Ehsan-ul-Haque, (2003), 'SME Development in Pakistan: Analyzing the Constraints on Growth', Pakistan Residential Mission Working Paper No.3, Islamabad: Asian Development Bank.

Dasanayaka. S (2006a) Development and Practice of SMEs - The Case of Sri Lanka Chapter in SME Development and Practice in the Asia Pacific region, Monash University, Malaysia Campus SME network publication (forth coming soon), Edward Elgar.

Dasanayaka. S (2006b) Development and Practice of SMEs - The Case of Pakistan in SME Development and Practice in the Asia Pacific region, Monash University, Malaysia Campus SME network publication (forth coming soon), Edward Elgar.

Federal Bureau of Statistics (2000), Economic Census - 2000, Pakistan

Federal Bureau of Statistics (2004), Economic Survey - 2003-04, Pakistan

ILO/SMEDA (2002), Creating a Conducive Policy Environment for Micro, Small \& Medium-Sized Enterprises in Pakistan. ILO/SMEDA, SEED Working Paper No.29. (Geneva, 2002).

Bari.F and Ul Haq.B (2002), Barriers in SME growth, LUMS (Lahore Management School), Pakistan

Nelson.O and Dasanayaka.S (2006), Small and Medium Scale Enterprises Development through Business Incubators, The Case of Sri Lanka, paper presented for SME-Entrepreneurship Global Conference 2006, Monash University Malaysia Campus, 15-17 October 2006. This soon coming as publication in SME Journal.

SMEDA (2006), Developing SME Policy in Pakistan, SME Issues Paper for deliberation by SME task force, Policy Planning and Strategy Dept, Ministry of Industries and Production in Pakistan. http://www.smeda.org.pk

World Bank/SMEDA (2003) Investment Climate Survey, Pakistan

World Bank (2002) Survey for SMEs Policy Note, Pakistan 


\section{“HABITS” DEFINED}

"For our purposes, we will define a habit as the intersection of knowledge, skill, and desire.

Knowledge is the theoretical paradigm, the what to do and the why. Skill is the how to do. And desire is the motivation, the want to do. In order to make something a habit in our lives, we have to have all three.

I may be ineffective in my interactions with my work associates, my spouse, or my children because I constantly tell them what I think, but I never really listen to them. Unless I search out correct principles of human interaction, I may not even know I need to listen.

Even if I do know that in order to interact effectively with others I really need to listen to them, I may not have the skill. I may not know how to really listen deeply to another human being.

But knowing I need to listen and knowing how to listen is not enough. Unless I want to listen, unless I have the desire, it won't be a habit in my life. Creating a habit requires work in all three dimensions.

The being/seeing change is an upward process - being changing seeing, which in turn changes being, and so forth, as we move in an upward spiral of growth. By working on knowledge, skill, and desire, we can break through to new levels of personal and interpersonal effectiveness as we break with old paradigms that may have been a source of pseudo-security for years.

It's sometimes a painful process. It's a change that has to be motivated by a higher purpose, by the willingness to subordinate what you think you want now for what you want later. But this process produces happiness, "the object and design of our existence." Happiness can be defined, in part at least, as the fruit of the desire and ability to sacrifice what we want now for what we want eventually."

Stephen R. Covey 